\title{
BIOLOGICAL AND CONTROL STUDIES ON RHOPALOSIPHUM PADI INFESTING WHEAT PLANTS, TRITICUM AESTIVUM AT MENOUFIA GOVERNORATE, EGYPT
}

\author{
Nehal O. Swelam ${ }^{(1)}$ and M. A. Tahon ${ }^{(2)}$ \\ ${ }^{(1)}$ Economic Entom. and Agric. Zoology Dept., Faculty Agric., Menoufia University, Egypt. \\ nehal.swelam@agr.menofia.edu.eg \\ (2) Central lab. of residue analysis of pesticides and heavy metal, Agric. Res. center, \\ Egypt. \\ mohamed828@gmail.com
}

Received: Oct. 27, 2021

Accepted: Nov. 7, 2021

\begin{abstract}
Seasonal fluctuations of wheat aphid, Rhopalosiphum padi L., infesting five wheat varieties, were investigated under field conditions along 2020/2021 season at Menoufia governorate, as well as, biological and biocontrol studies on this pest were conducted, moreover, residual of pesticides were determined in seeds, straw and soil of treated wheat plants.

As for the population density of $R$. padi, the highest numbers were recorded in March 2021 on Gemiza 11 variety. The life cycle of $R$. padi lasts 10.6 days \pm 0.5 , the adult viviparous female lived $12.2 \pm 0.4$ days spends two days without putting larvae, put $28.4 \pm$ 1.3 individuals during the reproductive period $(10.2 \pm 0.4)$ days, the life span lasts $20.8 \pm$ 0.8 days.

Abamectin $3.6 \%$ EC (double dose) and Congest 15\% SC were effective in reducing the number of aphids per leaf, recording $46.67-100 \%$ reduction and recording residues in wheat straw and wheat seeds less than the maximum residues limits. The tested treatments did not affect the germination process. The tested bio agents as nonconventional insecticide could be considered suitable for aphid control and safe for human and environment. It could be recommended the use of Abamectin and Imidacloprid in integrated aphid management programs.
\end{abstract}

Key words: Biology, Ecology, Biocontrol, Bio-assessment, residual analysis, Wheat aphid.

\section{INTRODUCTION}

Wheat crop, Triticum aestivum is considered the main aspect of food safety in Egypt; it is the largest importer of wheat cosmopolitan. Egyptians depend on bread as the main component of the meal (FAO, 2015). Wheat plants attacked with many pests causing great loss in the yield. The aphid, Rhopalosiphum padi, is one of the most harmful pests that affect wheat production all over the world; it has two ways of damage, the direct damage caused by the insects themselves when they suck the plant sap, and the indirect damage caused by the viruses transported by the aphid mouthparts (Tantawi et al., 1986, Blackman and Eastop 1986). The late sown wheat faces aphid outbreaks causing great damage (Bhambhro 2002). EL-Mitwally et al., 2013 studied the density of $R$. padi on the five wheat varieties: Giza 168, Sids 1, Gemiza 7, Gemiza 9, and Sakha 93 for two years in Egypt, and found that there were significant differences among the five tested varieties for $R$. padi population dynamic and density, reporting that Sids 1 was the most susceptible to $R$. padi, while Sakha 93 variety was the least. Araya et al., 1987 elucidated after a study of $R$. Padi population along two seasons 
that, the most convenient weather is in mid-October and early March, while Ullah et al., 2020 indicated that the highest population of $R$. Padi recorded after the mid of March and the least numbers recorded during the first week of February. The increase in wheat seeds size, without any changes on grain number, results great increases in a yield boost under field conditions (Calderini et al., 2020).

From the previous review, the present study was conducted to throw the light on the ecology, biology and control of wheat aphid, Rhopalosiphum padi L., infesting five wheat varieties under field conditions, as one of the important pests of wheat in Egypt.

\section{MATERIALS AND METHODS}

\section{1- Ecological studies}

Air temperature and relative humidity were monthly counted (Table 1) noted daily during the study period.

Wheat varieties under study were Misr1, Sids 14, Giza 171, Gemiza 11, and Gemiza 12, were obtained from shopping center of the Ministry of Agriculture, planted as broadcasting method on 30 October 2020.

Fifteen days after planting, from each wheat variety, five wheat plants as a sample were collected from the study fields in cloth bags, samples were replicated five times, transferred to the laboratory and directly examined with a hand lens $10 x$ and the numbers of aphid stages were counted. Weekly samples were continued till the end of the experiment.

\section{2- Biological Studies}

Rearing cages (Fig 1) were modified to be lighter and smaller to not harm the plant leaf, (A plastic cylinder with a diameter of $2 \mathrm{~cm}$ and a height of $1 \mathrm{~cm}$ covered with a layer of muslin gauze and mounted on a $6 \mathrm{~cm}$ metal hair clip with a circular base of $3 \mathrm{~cm}$ made of foam to act as a support for the plant sheet to strength the weight of the hollow part of the cages).

Ten adult females (viviparous) were selected as the source of the obtained larvae. The individuals (50 larvae) were put separately under the modified cage and daily examined with a hand lens $10 \mathrm{x}$ with the aid of a fine brush, and the results were tabulated as Darwish (1983a), Gautam and Verma (1983), and Swelam (2012) elucidated.

\section{3- Control Studies:}

The experiment was applied under field conditions to obtain a clear image about the benefits or the disadvantages of the pesticide application that will have been happen.

Table (1): Temperature and relative humidity during the season of 2020/2021.

\begin{tabular}{|l|c|c|c|c|}
\hline \multirow{2}{*}{ Month } & \multicolumn{2}{|c|}{ Temperature ${ }^{\circ} \mathbf{C}$} & \multicolumn{2}{c|}{ R.H\% } \\
\cline { 2 - 5 } & min. & max. & min. & max. \\
\hline October, 2020 & 24.1 & 28.9 & 33.2 & 84.6 \\
\hline November, 2020 & 17.1 & 23.2 & 43.7 & 78.4 \\
\hline December, 2020 & 14.5 & 21.6 & 38.1 & 78.3 \\
\hline January, 2021 & 13.3 & 21.7 & 37.9 & 83.0 \\
\hline February, 2021 & 9.9 & 22.5 & 34.4 & 87.0 \\
\hline March, 2021 & 13.8 & 31.4 & 30.5 & 73.4 \\
\hline April, 2021 & 15.0 & 34.5 & 19.8 & 71.6 \\
\hline
\end{tabular}




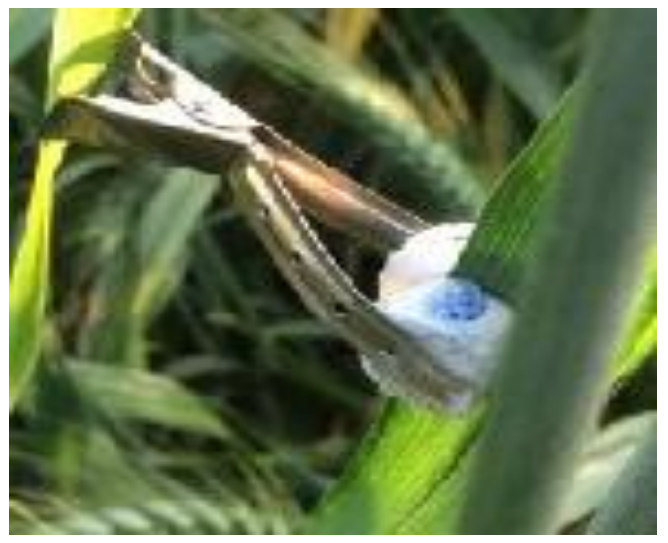

Figure (1): The modified rearing cage where the larva put under it to be examined daily.

Two pesticides (Table 2) were applied as a spray with the aid of dorsal ordinary sprayer $(20 \mathrm{~L})$ on wheat plants (Gemiza 11 variety) 120 days old in three isolated areas of the field, and a control unit was accompanying the three treatments which were sprayed with water only, every treatment was replicated five times.

\section{Abamectin $3.6 \%$ EC:}

Abamectin is a widely used insecticide and anthelmintic, a member of the Avermectin family and is a natural fermentation product of soil dwelling actinomycete Streptomyces avermitilis, was obtained from KZ Company for Agricultural pesticides and fertilizers, Egypt.

\section{Congest $15 \%$ SC:}

Congest is systematic, a mixture of Abamectin 3\% EC, Imidacloprid 12\% SC, used to control agriculture pests targeting nervous system of insects, obtained from Starchem Company for chemicals, Egypt.

\section{4- Residual Analysis:}

At the end of control experiment, samples were collected from soil, seeds, and straw after harvest. Samples were put in poly-ethylene bags and transferred to the laboratory where it was immediately subjected to analysis in order to determine the Abamectin and Imidacloprid residues.

Abamectin (3.6\% EC) and Congest 15\%SC (Abamectin 3\% + Imidacloprid $12 \%$ SC), was obtained from local pesticide stores.

The analytical standard of Imidacloprid $(99.9 \%$ purity) was purchased from Sigma-Aldrich and abamectin analytical applied for the residue standards was purchased from Dr Ehrenstorfer (LGC Standards; Augsburg, Germany). All solvents were purchased from Merck (Darmstadt, Germany).

\section{Extraction cleanup:}

Two grams of homogenized samples (wheat seeds, wheat straw and soil) were placed into $50 \mathrm{~mL}$ centrifuge tubes and $10 \mathrm{ml}$ of deionized water mixed with the weighed portion. Vortex was used for mixing the mixture $(5 \mathrm{~s})$ then left for 10 min for hydration. Acetonitrile $(10 \mathrm{ml})$ was added and mixed with sample by using Sample Prep 2010-230 Geno/Grinder (SPEX Sample Pre, UK) at $700 \mathrm{rpm}$ for 4 min. After addition of buffer-salt mixture the sample was centrifuged for $5 \mathrm{~min}$ at $4000 \mathrm{rpm}$, and the aliquot was filtrated by syringe filter $(0.45 \mu \mathrm{m})$ before LC-MS/MS injection (Lie et al., 2020). 
Table (2): Common names and used concentrations of tested treatments

\begin{tabular}{|l|c|c|}
\hline Common name & Applied concentration & \multirow{2}{*}{ Rate/ feddan } \\
\cline { 1 - 2 } Abamectin 3.6\% EC & $5 \mathrm{ml} / 20$-liter water & \multirow{2}{*}{120 liters / feddan } \\
\cline { 1 - 2 } Abamectin 3.6\% EC & $10 \mathrm{ml} / 20$-liter water & \\
\hline Congest $15 \% \mathrm{SC}$ & $5 \mathrm{ml} / 20$-liter water & \\
\hline
\end{tabular}

Measurement and residues via HPLC:

Agilent 1260 Series instrument (HPLC) was used for separation coupled to an API 6500 Qtrap tandem mass spectrometer from $A B$ Sciex with electrospray ionization (ESI) interface. C18 column was used for separation (ZORBAX Eclipse XDB-C18 $4.6 \times 150 \mathrm{~mm}$, $5 \mu \mathrm{m}$ particle size) (Agilent, USA). The mobile phase was as follows: Solvent $A$ : $10 \mathrm{mM}$ ammonium format solution at $\mathrm{pH}$ $4 \pm 0.1$ in methanol-water (1:9); Solvent $B:$ methanol. The linear gradient program was: start at $100 \% A ; 0-13 \mathrm{~min}$ from $100 \%$ to $5 \% A$; $13-21$ min $5 \% A$; $21-28$ min from $5 \%$ to $100 \%$ A; $28-32 \mathrm{~min} 100 \%$ $A$ at a flow rate of $0.3 \mathrm{ml} / \mathrm{min}$. The source was adjusted in the positive mode while nitrogen nebuliser, curtain and other gas parameters were optimized according to the manufacturer recommendations. A source temperature $\left(400^{\circ} \mathrm{C}\right)$ and ion spray potential $(5500 \mathrm{~V})$ was common for all compounds. Decluster potential and collision energy was in tune by injecting direct infusion from individual pesticide solutions into MS detector. Multiple reactions monitoring mode was used for quantitation and confirmation ( $\mathrm{Li}$ et al., 2020).

\section{Standard solution preparation:}

$1000 \mathrm{mg} / \mathrm{L}$ of stock solutions for each pesticide were prepared in acetonitrile or methanol. According to the analysis, a stock of multi-standard solution containing $10 \mathrm{mg} / \mathrm{L}$ of each pesticide was prepared in acetonitrile then, stored at $-20{ }^{\circ} \mathrm{C}$. To avoid the degradation of the analytes, various concentrations of standard working solutions was needed by preparing daily appropriately diluting the stock multistandard solutions in blank matrix extracts or acetonitrile. All solutions were filtered through membrane $(0.22 \mu \mathrm{m})$ prior to analysis.

\section{Matrix effect (ME):}

To assess the matrix effect, serial concentrations $(5 \mathrm{ng} / \mathrm{ml}, 20 \mathrm{ng} / \mathrm{ml}, 50$ $\mathrm{ng} / \mathrm{ml}, 100 \mathrm{ng} / \mathrm{ml}$, and $200 \mathrm{ng} / \mathrm{ml}$ ) of standards. Where ME was calculated as follow: $M E(\%)=$ kmatrix/ ksolvent $\times 100$, kmatrix is the slope of the matrixmatched calibration curve and ksolvent is the solvent-only calibration curve.

\section{5- Biological assay:}

After harvesting the control treatments, one hundred seeds from the treated wheat variety, were weighted to compare with that obtained from the Ministry of Agriculture, as a check sample. Treatments were replicated five times.

The treated wheat seeds variety Gemiza 11 were estimated for germination, where five replicates consist of twenty seeds were put on a wet cotton pod in a $15 \mathrm{~cm}$ petri dish, covered with a dark cloth and irrigated as required. Germination percentages were calculated GP $=A^{\circ} / A$ X100 (Al- Saady 2015) where $\left(A^{\circ}\right)$ no. germinated seeds (A) Total number of seeds. 


\section{6- Statistical analysis:}

Data were subjected to the analysis of variance test (ANOVA) as randomized complete blocks design. The least significant differences (LSD) at the $5 \%$ level were determined using a computer program (CoStat, 2008) and Duncan's Multiple Range testes and LSD 5\% values were used to compare the average mean numbers.

Reduction percentages were counted according to Abbott's formula.

Increase or decrease \% =

Control - treatment / Control x 100

Reduction percentages were counted according to the formula of Henderson and Tilton (1955) and (Fleming and Retnakaran, 1985).

Reduction \%=

$\left[1-\frac{\text { treament after }}{\text { treatment before }} \times \frac{\text { control before }}{\text { control after }}\right] \times 100$

\section{RESULTS AND DISCUSSION}

Population dynamics of wheat aphid, $R$. padi, on five cultivated wheat varieties:
The obtained results illustrated in Figure (2) revealed that Gemiza 11 variety was the most susceptible one to wheat aphid, and Giza 171 was less susceptible, while Gemiza 12, Misr 1, and Sids 14 have no significant differences in their susceptibility to $R$. Padi, meanwhile it could be reported that they have good tolerance to the infestation with $R$. padi. Furthermore, the highest numbers of $\boldsymbol{R}$. padi were recorded in March month with 13.8- $31.4{ }^{\circ} \mathrm{C}$ and $30.5-73.4 \mathrm{RH} \%$.

These results are different from that elucidated by (El-Mitwally et al., 2013) who studied the density of $R$. padi on five wheat varieties: Giza 168, Sids 1, Gemiza 7, Gemiza 9, and Sakha 93 for two years in Egypt, and found that there were significant differences among the five tested varieties for $R$. padi population dynamic and density, reporting that Sids 1 was the most susceptible to $R$. padi, while Sakha 93 variety was the least.

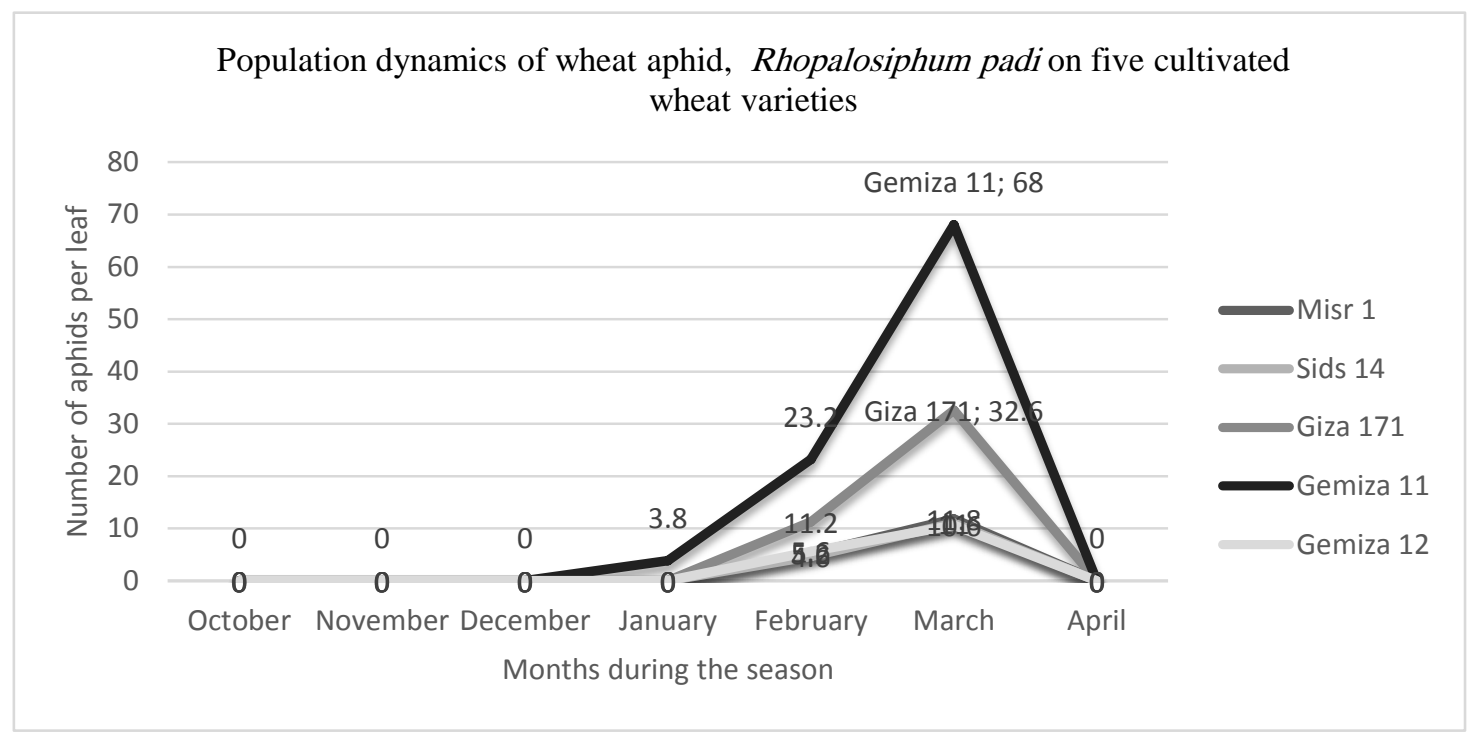

Figure (2): Population dynamics of wheat aphid, R. padi, on five wheat varieties 
Biology of Rhopalosiphum padi on Triticum aestivum Gemiza 11 variety:

The obtained data in Table (3) elucidated that the life cycle of $R$. padi lasts for 10.6 days with \pm 0.5 standard error and this means that the larva needs $10.6 \pm 0.5$ days to put another larva. The adult viviparous female lived $12.2 \pm 0.4$ days spends two days without putting larvae, one day was the pre-viviposition period and this period is from the last molt to the first larva put, the other day was the post-reproductive (postviviposition) period is from the last larva put to the death, the adult viviparous female put $28.4 \pm 1.3$ individuals during the reproductive period $10.2 \pm 0.4$ days. The sum of the life cycle and the reproductive period and the post reproductive period called the life span which lasted $20.8 \pm 0.8$ days, this indicated to the high reproductive efficiency of this pest. So, R. padi causes huge losses when the suitable conditions are available.

\section{Control studies:}

Three treatments were tested against R. padi infesting wheat plants Gemiza 11 under field conditions. The data in Table (4) show that the highest reduction percentages of $R$. padi, after 24 hours were recorded at the treatment of Congest $15 \%$ with the concentration of 5 $\mathrm{ml} / 20$ liters of water, followed by the treatment of Abamectin 3.6\% (Double dose) while the treatment of Abamectin $3.6 \%$ occupied the least. The same trend was observed at $72 \mathrm{hrs}, 7$ days and 10 days of treatment.

Table (3): Biology of $\boldsymbol{R}$. padi reared on wheat, in Meet mousa, Menoufia, March 2021

\begin{tabular}{|l|l|cc|}
\hline \multirow{2}{*}{ Biological aspects } & \multicolumn{2}{c|}{ Period in days } \\
\cline { 3 - 4 } & Immature stages & \multicolumn{2}{c|}{ Mean \pm S.E. } \\
\hline \multirow{2}{*}{ Pre-reproductive } & 8.6 & \pm 0.5 \\
\cline { 2 - 4 } & Pre-viviposition & 1.0 & \pm 0.0 \\
\hline Reproductive & Viviposition & 10.2 & \pm 0.4 \\
\hline Post-reproductive & Post-viviposition & 1.0 & \pm 0.0 \\
\hline Life cycle & & 10.6 & \pm 0.5 \\
\hline Adult longevity & 12.2 & \pm 0.4 \\
\hline Life span & 20.8 & \pm 0.8 \\
\hline Mean no. of produced young's / female & 28.4 & \pm 1.3 \\
\hline
\end{tabular}

Values are means of 10 replicates of apterous viviparous adult's \pm Standard Error.

Table (4): Reduction \% in R. padi numbers per leaf after pesticide applications

\begin{tabular}{|l|c|c|c|c|}
\hline \multirow{2}{*}{ Treatments } & \multicolumn{4}{c|}{ Reduction\% in aphids/ leaf } \\
\cline { 2 - 5 } & 1 day & 3 days & 7 days & 10 days \\
\hline Abamectin 3.6\% & 63.83 & 54.72 & 59.79 & 46.67 \\
\hline Abamectin 3.6\% (double dose) & 86.64 & 80.87 & 90.93 & 92.05 \\
\hline Congest15\% (Abamectin 3 + Imidacloprid 12) & 92.05 & 89.17 & 93.73 & 100 \\
\hline
\end{tabular}




\section{Biological assay:}

Data in Table (5) show the weights of wheat seeds from each replicate of different treatments. Results indicated that the treatment of Abamectin 3.6\% (double dose) gave the highest weights of seeds, followed by the treatment of Abamectin $3.6 \%$, while the least weight was recorded with the treatment of Congest $15 \%$ (Abamectin $3 \% \quad+$ Imidacloprid 12\%) in comparison with untreated control.

Data in Table (6) show the germination percentage of wheat seeds from each treatment. Results indicated that the all the treatments have non-significant impact on the germination of the wheat seeds compared with the non-treated seeds.

\section{Residual analysis:}

The obtained results in Table (7) showed that the postharvest residues of the treatments of Abamectin $3.6 \% \mathrm{EC}$, Abamectin $3.6 \%$ EC (double dose) and Abamectin $3 \%$ EC were $(0.001,0.006$ and 0.0038), (0.0014, 0.0072 and 0.0055$)$ and $(0.0035,0.0046$ and 0.0031$) \mathrm{mg} / \mathrm{kg}$ in soil, wheat straw and wheat seeds, respectively, compared with control which revealed no peak in the treatments.

As for the postharvest residues of the Imidacloprid $12 \%$ SC treatment, data in Table (8) showed that the residues were $0.0251,0.0211$ and $0.118 \mathrm{mg} / \mathrm{kg}$ in soil, wheat straw and wheat seeds, respectively, compared with control which revealed no peak in the treatments.

Table (5): Mean values of the weights of wheat seeds after pesticides applications

\begin{tabular}{|c|c|c|c|c|c|c|c|}
\hline \multirow{2}{*}{ Treatments } & \multicolumn{5}{|c|}{ Weight g/ 100 seeds of wheat } & \multirow{2}{*}{ Mean } & \multirow{2}{*}{ \pm S.E. } \\
\hline & R1 & $\mathbf{R 2}$ & R3 & R4 & R5 & & \\
\hline Abamectin $3.6 \%$ & 7.5 & 7.6 & 7.5 & 7.5 & 7.6 & $7.54 \mathrm{~b}$ & 0.02 \\
\hline $\begin{array}{l}\text { Congest15\% (Abamectin 3\%+ } \\
\text { Imidacloprid 12\%) }\end{array}$ & 6.8 & 7.1 & 6.4 & 7.1 & 6.7 & $6.82 \mathrm{~d}$ & 0.13 \\
\hline Abamectin $3.6 \%$ (double dose) & 7.9 & 7.7 & 7.7 & 7.9 & 8.4 & $7.92 \mathrm{a}$ & 0.12 \\
\hline Control & 7.3 & 7.0 & 7.0 & 7.2 & 7.1 & $7.12 \mathrm{c}$ & 0.06 \\
\hline LSD 5\% & & & & & & & \\
\hline
\end{tabular}

mean values followed by the same letter are not significantly different by $(P=0.05)$ according to Duncan's multiple range test.

Table (6): Germination \% of wheat variety Gemiza 11 after pesticide applications.

\begin{tabular}{|l|c|c|}
\hline Treatments & Mean of Germination \% & \pm S.E. \\
\hline Abamectin 3.6\% & 96 a & 4 \\
\hline Abamectin 3\%+ Imidacloprid 12\% & 98 a & 2 \\
\hline Abamectin 3.6\% *2 & 98 a & 2 \\
\hline Control & $98 \mathrm{a}$ & 2 \\
\hline
\end{tabular}

Table (7): The residuals of the Abamectin 3.6\% analyzed in soil, wheat straw, and seeds.

\begin{tabular}{|c|c|c|c|}
\hline Treatments & Soil & Straw & Seeds \\
\hline ST. Matrix $0.05 \mathrm{mg} / \mathrm{L}-$ Wheat & 0.047 & 0.0303 & 0.0345 \\
\hline Spik sample Wheat & 0.043 & 0.0289 & 0.0377 \\
\hline Abamectin $3.6 \%$ EC & 0.0010 & 0.0060 & 0.0038 \\
\hline Abamectin $3.6 \%$ (double dose) & 0.0014 & 0.0072 & 0.0055 \\
\hline Abamectin 3\% & 0.0035 & 0.0046 & 0.0031 \\
\hline Control & no peak & no peak & no peak \\
\hline
\end{tabular}


Table (8): The residuals of the Imidacloprid $12 \%$ analyzed in soil, wheat straw, and seeds

\begin{tabular}{|l|l|l|l|}
\hline Treatments & Soil & Straw & Seeds \\
\hline ST. Matrix 0.05 mg/L- Wheat & 0.0425 & 0.0476 & 0.0733 \\
\hline Spik sample Wheat & 0.0436 & 0.0489 & 0.0689 \\
\hline Imidacloprid 12\% SC & 0.0251 & 0.0211 & 0.0118 \\
\hline Control & no peak & no peak & no peak \\
\hline
\end{tabular}

Although, the maximum residues limits (MRLs) of Abamectin have not been established in wheat straw and wheat seeds, we believe that this level is sufficient for estimation of residue with expected MRLs between 0.02-0.05 mg / $\mathrm{kg}$ for wheat seeds and from 0.1-0.5 mg/ $\mathrm{kg}$ for wheat straw. So, from the obtained data it is obvious that the residues of Abamectin $3.6 \%$ EC, double field recommended dose of Abamectin $3.6 \%$

EC and Abamectin $3 \%$ EC in wheat straw and wheat seeds were less than expected MRL.

The residues of Imidacloprid $12 \%$ SC in wheat seeds were less than MRL 0.05 $\mathrm{mg} / \mathrm{g}$, where the level of residues in straw was less in all treatments. Straw levels can be considered safe in animal feeding because of higher MRL of $\mathrm{mg} / \mathrm{g}$ as defined by Codex alimentraius.

\section{REFERENCES}

Al-Saady, H. A. (2015). Germination and Growth of Wheat Plants (Triticum aestivum L.) Under Salt Stress. J Pharm. Chem. Biol. Sci.; 3(3): 416420.

Araya, J. E., J. E. Foster and S. E. Cambron (1987). A study of the biology of Rhopalosiphum padi (Homoptera: Aphididae) in winter wheat in Northwestern Indiana. The great lakes Entomologist, 20 (I): 47-50.

Bhambhro, S. (2002). Threat of aphids to wheat crop. DAWN-Business, the Internet

Edition. https://www.dawn.com.

Blackman, R. and V. Eastop (1986). Aphids on the world's crops: An identification and information guide: John Wiley and Sons 466 pp.

Calderini, D. F., F. M. Castillo, A. ArenasM, G. Molero, M. P. Reynolds, M. Craze, S. Bowden, M. J. Milner, E. J. Wallington, A. Dowle, L. D. Gomez and S. J. McQueen-Mason (2021). Overcoming the trade-off between grain weight and number in wheat by the ectopic expression of expansion in developing seeds leads to increased yield potential. New Phytologist, 230: 629-640 doi: 10.1111/nph.17048.

Codex alimentarius (2013). Pesticides residues in food 206 Imidacloprid.

CoStat 6.400. (2008). Statistical CoHort Software program, Copyright (c) 19982008 CoHort Software 798 Lighthouse Ave. PMB 320 Monterey CA, 93940 USA.

El-Mitwally, M. F., F. F. Shalaby, M. M. Assar and A. M. Khorchid (2013). Response of Rhopalosiphum padi L. to some biotic, abiotic factors and phytochemical components of five wheat varieties. Egyptian Journal of Agriculture Research, 91 (4): 13931405.

Fleming, R. and A. Retnakaram (1985). Evaluating single treatment data using Abbot's formula with reference to insecticides. J. Econ. Entom. 78: 1179 $-1181$.

Food and Agriculture Organization (FAO) of the United Nations, Rome (2015). Egypt wheat sector review. Julian McGill, http://www.fao.org/3/i4898e/i4898e. 
Henderson, C. F. and W.Tilton (1955). Tests with acaricides against the brown wheat mite. Journal of Econ. Ent. 48: $157-161$.

Li, R.-X., M.-M. Li, T. Wang, T.-L. Wang, J.Y. Chena, F. Francis, B. Fana, Z.-Q. Konga, and X.F. Daia (2020). Screening of pesticide residues in traditional Chinese medicines using modified QuEChERS sample preparation procedure and LC-MS/MS analysis. Journal of Chromatography B 1152 (2020) 122224.

Tantawi, A. H., A. H. Etman, and M. A. Eglal. (1986). Aphid species on wheat plants in Egypt. Changes in their relative abundance and correlation of their initial and maximum infestation with the state of plant growth. J. Agric. Res., Tanta Univ., 12 (2): 549-565.

Ullah, F., H. Gul, F. Said, A. Ali, K. Tariq, $M$. Zaman and D. Song (2020). Population dynamics of wheat aphids, Rhopalosiphum padi (Linnaeus) and Sitobion avenae (Fabricius) at district Mardan, Khyber Pakhtunkhwa Pakistan. Pure \& Applied Biology,9 (1): 27-35. http://dx.doi.org/10.19045/bspab.2020. 90004. 


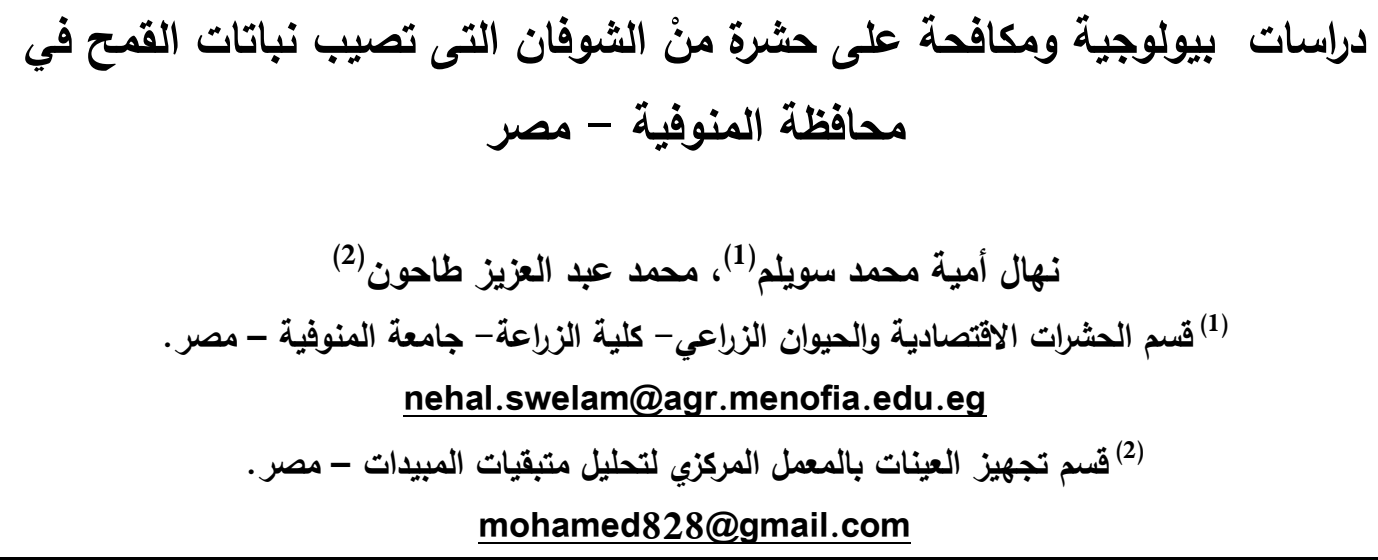

